\title{
ARCHITECTURAL SPACE IN DANCE AS AN ARTISTIC AND FIGURATIVE SYSTEM
}

Summary: The study examines the expressive means of dance and architecture, establishes common and specific areas in the nature of their artistic language, identifies the extent of interaction between architectural principles with dance dramaturgy and choreographic composition, and analyzes examples of interpretation of dance production solutions in the architectural space. Through a simultaneous review, the author examines the expressive means of dance and architecture, establishing the common and the specific in the expressive and pictorial nature of their artistic language. The focus is on identifying the degree of influence of architectural principles on the dance drama, choreographic composition, and the reverse impact. The analysis provides examples of the interpretation of dance staging solutions in the architectural space, including innovative modern practices of the 20th-21st centuries. The artistic and imaginative metamorphoses of staged choreographic solutions occurring in different kinds of architectural spaces are considered. Starting with the perspectivism of the scenery on the stage and the light architecture of the 18th century, the author moves on to the monumental construction of the large stage performance of the 19th century and concludes with the choreographic experiments of the early 20th century. The article points out that modern times offer the most curious design solutions. There are examples of bold, original methods of interaction between choreography and architecture: dances are staged

Dance in architectural space is a complex, multidimensional problem lying at the intersection of art, philosophy, and engineering technology. This study examines this topic as an artistic and aesthetic category in the context of the expressive means of choreographic art, which finds its creative understanding and diversity of forms of artistic representation of space through dance.

While the modern scientific literature sufficiently covers the matters of the morphology of dance and its linguistic nature, the issues of architectur- directly in the interiors of buildings, bypassing the traditional stage platform. The implied idea of human movement in space, encompassing the viewer, appears here because of successively changing impressions. Finally, the author explores the directorial approach, where the choreography itself masters and constructs the architecture, helping the viewer to perceive themselves as if within its own spatial structure. This peculiar artistic and visual synthesis appears in the dynamics of genre and style of the author's stage context. The study of the specifics of ballet as a dramatic phenomenon seems to be a fundamental research task, because, more than any other theatrics genre, it is the ballet that provided extremely diversified artistic samples of space and stage creativity in the heritage of the 20th century, and probably, will continue to do so in the 21st. The question of dance interpretation in the architectural space is a significant independent subject of research in connection with the structure and evolution of the artistic image in contemporary choreographic art. Against the background of postmodernist modern style trends as a global creative principle of post-culture, this topic includes broad general aesthetic associations. It is vital to the understanding of the artistic process in contemporary art in general.

Keywords: architectural space, dance functioning, choreographic drama, artistic and figurative system, synthesis of architecture and dance

al space as a necessary substance existing in the choreographic art rarely become an object of researchers' attention. Stage space, from its origins to modern times, shaped by the methods of scenography, was the subject of Viktor Berezkin's analysis. [1] Future choreographers study space as an expressive means in dance composition during training courses, which allows them to form a conscious attitude and motivation in working with the scenography whole. Jean-Georges Noverre considered the stage as a geometrical system in the context 


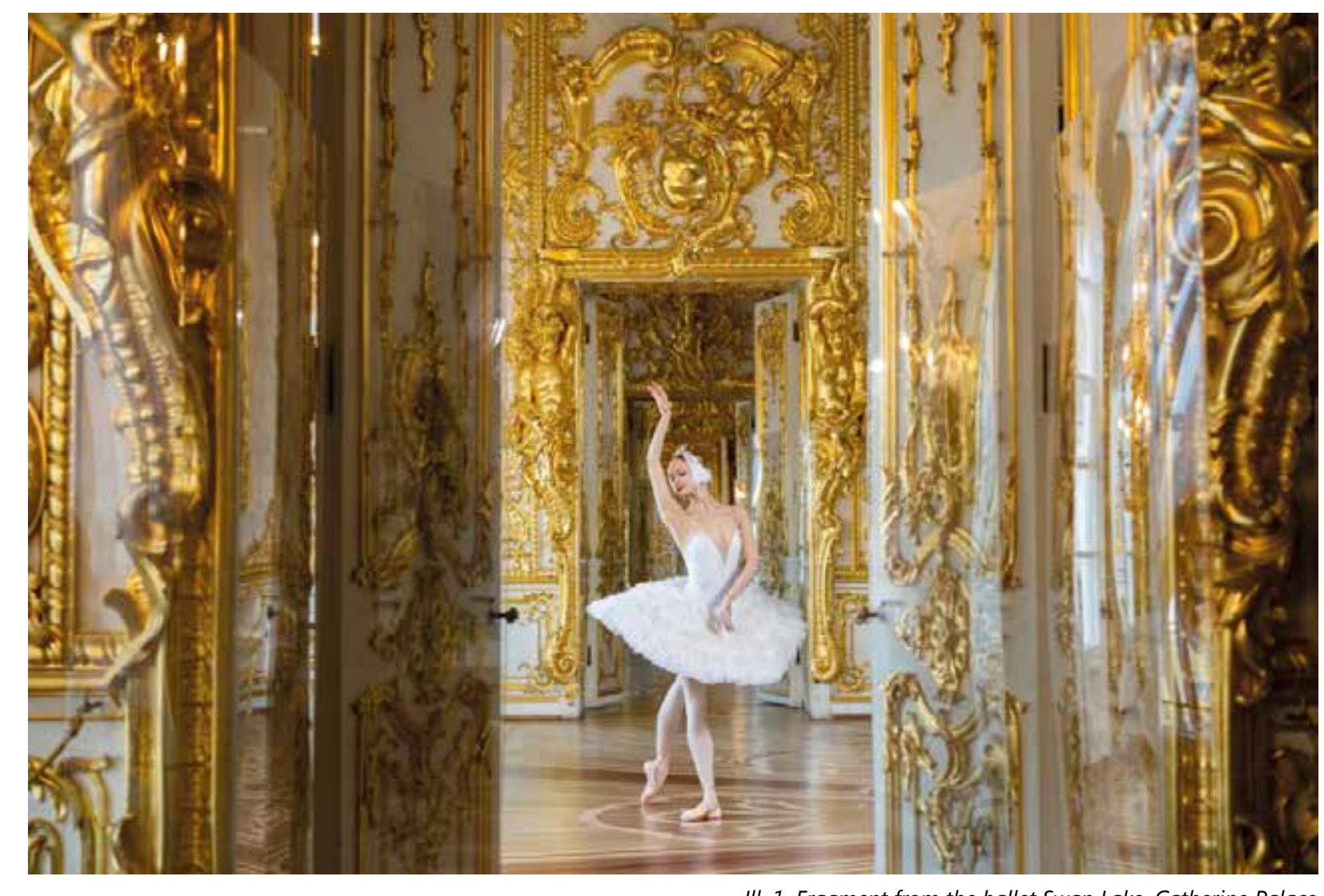

III. 1. Fragment from the ballet Swan Lake. Catherine Palace

of understanding the compositional activity of the dancer and the organization of dance elements to create a coherent harmony of the choreographic composition. [2;3]

The problem posed in this article is somewhat touched upon in the ballet literature in connection with the reflections of dance theorists, as well as in the context of the work of several choreographers such as Marius Petipa, Mikhail Fokin, Kasyan Goleizovsky, Leonid Yakobson, Yury Grigorovich, Boris Eifman, Martha Graham, Rudolph von Laban, Merce Cunningham, Maurice Béjart, and Yevgeni Panfilov. They reflected on a conceptual, artistic, and spatial vision of dance nature. $[4 ; 5 ; 6]$ According to them, space is a peculiar object of choreographic content, necessary to be reinterpreted each time. Yulia Churko described the techniques of contemporary choreography functioning in the context of the aesthetics of performativity as a way of forming new connections between elements of artistic and spatial composition, taking the viewer's perception into account. [7]

A significant group of studies considers the theatrical space as a philosophical category. [8;9;10] For instance, Galina Lebedeva, operating with the concepts of ballet, semantics, and architectonics from the position of the system approach and synerget- ic paradigm, analyzes the spatial and temporal parameters of the ballet performance and the specifics of interaction between its components. [11] Olga Gerdt, in her study Territory of possibilities. In motion, proposes to consider the changeable nature of the performer's plasticity, which allows different spatial mean cluded in the spatial environment, it can reveal the multiplicity of ways of understanding the theatrical image and provide the potential for the emergence of new relationships to its content. [12]

Now you can find reflections on the integrative principle of modern architecture: "The multi-element forms of creativity, primarily theater, film, television, and modern choreography, correlate with current architectural trends of 'directing' and 'spectacle'". Despite the conventionality of this relationship, some phenomena and approaches in the sphere of the performing arts can be described as actual principles of architecture: scenarity, emphasized visual expressiveness, the construction of volumes and spaces as 'mise en scène' of the performance, the architectural 'set' and the change of 'frames' spatial impressions in motion. [13] Indeed, the art of architecture, as well as the art of dance, has long followed the law of artistic integration, so architects and choreographers employ artistic synthesis as kind of complex integrative method of professional activity. [14; 15;16]

However, despite the mentioned sources, art history still lacks a full-fledged analytical approach from the perspective of the architectural component of a ballet piece.

The methodological concept of the study relies on the principles of holistic research of the dance in the architectural space: from the philosophical aesthetic, artistic, and imaginative issues of its consideration to the linguistic and stylistic ones. Exploring some historical aspects of the synthesis of dance and architecture, we evaluate the events and phenomena of theatrical life from a modern perspective, given that the chosen topic, the collaboration of the playwright, director, and architect, has direct relevance to the creative practice of modern days that is relevant not only for Russian but for the multinational theater as well.

A solid architectonic structure should be at the heart of any choreographic performance. Konstantin Stanislavsky held the art of mise en scène in high regard, demanding a precise scheme for an actor's movements in space. He called the actor the engineer, the architect of the role. "No choreographic image can exist without a spatial structure without a well-thought-out constructive principle, which determines the pulse of the entire production. The corps-de-ballet masses, formed in various ways during the performance, also shape a spaarchitectonics of a ballet performance consists of two verbal components. One goes into the image the artistic design, and the organization of space the other remains in the dance." [17: c. 170]. Oskar Remez noted: "Directing is a construction art". [18: p.103] Finding a spatial principle for a performance is a fascinating task for a choreographer but never an easy one.

The sixteenth-century stage in Italy, a box in the setting of court architectural performances and primitive fairgrounds on which vagarious actors entertained the crowds gathered in the square, created two systems of theatrical spaces, which can be identified as closed and open spaces. The closed space exists on the stage, inside the interior of the theater building. The open space spread to the natura and architectural environment. The French choreographer Maurice Béjart characterized architecture as an art that seriously influenced ballet: "I worked a lot with architects, maybe not very famous ones.
They created a new stage space for me, an important element of the performance. My best performances go on the Italian stage with the canvas rising On. Every time I arrange my stages differently." [19: p.7-8]

Since the 16th century, the stage has been developing the techniques of perspectivism. It can deepen the architectonics of the stage action vis ually. Even conventionally abstract sets with the image of architectural structures can emphasize and strengthen the spatial and visual development of the performance, the mutual conditionality of the dancers and the environment. The juxtaposition of linear perspective in two-dimensional Renaissance decoration with the space of actual architecture unwittingly leads to an illusory convergence of the ontological systems of these types of creativity.

You can observe a different concept of space based on the relationship between light architecture and dance. It is not an invention of the modern era by any means. In a latent form, it had already been incorporated into the figurative structure of the eighteenth-century architecture of the royal pleasure residences of Moscow and Saint Petersburg: Tsaritsyno, Arkhangelskoye, Kuskovo, Ostankino, and Peterhof where theatricalization was particularly important. The very architecture of these ensembles with their regular planning principles was designed for the atrical spatial play, the change of processions, and acquired a theatrical character. The landscape architecture of the time was considered an art form, equal to others. The extravaganza created by the decorative nature of colored lanterns gave rise to an image of illusory light architecture, becoming a generator of unfolded space, although it has not yet achieved a geometric logic of light beams similar to modern stage apparatus in terms of its organization. At the same time, here we should consider the conventionality of the stylistic characteristic of the architectural ensembles themselves and the lack of clear boundaries between them. Sometimes eners, and theatrical event izers combined features of several different styles and worked at their junction, relying on decorative and emotional principles rather than functional and technical ones, thus complementing the structura plastic with ornamental one.

Marius Petipa and Lev Ivanov's monumental construction of a large stage performance, Kasyan Goleizovsky's constructivist experiments, the movement of dance forms, their transformation and juxtaposi- 
tion by George Balanchine: all these are examples of the use of different spatial systems. The figures of the performers themselves create the architecture, orienting the viewer to their own spatial structure. The dancers of Petipa and Ivanov gravitate towards symmetry of forms and synchronous ensemble while preserving the lively spontaneity of each image. The corps de ballet groups of Swans, Willis, and Shadows in Swan Lake, Giselle, and La Bayadère, almost genetically created that astonishing dance geometry, without which the choreography of these ballets is unthinkable, by lining up in parallel, diagonal, and other rows on the stage floor. Kasyan Goleizovsky, the experimental choreographer of the early twentieth century, often reduced acting groups to elementary schematic simplicity. The direction acquired through sophistication was pointed upwards: it is vertical, not horizontal (like in the case of Ivanov and Petipa). He used stairs, bridges, and other architectural elements in his design (so there was an interaction between the architectonic structure of the design and the tectonics of the figures of the performers in space). It was the most extreme manifestation of choreographic tectonic rationalism (1920), whose naked constructiveness was so consonant with the architectural pursuit of the time. In this form, the abstract prop buildings find their place as the subject filling of the stage environment and interact with the rationalist architecture in unison, as elements connected to it, bringing their constructional and volumetric emphasis to the choreography.

"One example of the bold, original method of interaction between choreography and architecture can be the staging of dances directly in the interiors of buildings, bypassing the traditional stage platform. The idea of a person moving in space from hall to hall, the excitement that embraces the viewer because of the change of specific, consistently changing impressions, was clearly revealed in the production of choreographic miniatures by Leonid Yakobson in the halls of the Museum of Ceramics at the Kuskovo Estate. The basis of the composition was an open space, a suite of halls without any clearly delineated borders and symmetrical axes, but still subjected to a certain rhythmic regularity. Thi space is neither topographical nor mathematical but rather alive and active. The dance movement leads from one hall to another. There is a vigorous unfolding of the action, an abrupt alternation of scenes, a quick change of backgrounds, a play on details, foreshortening glance. As the gaze moves, numerous architectural elements and details (doors, openings, windows, columns, chandeliers, decorations, etc.) enter the field of view, participating in the crespaces, forms, textures, and directions give rise to the multiplicity of impressions that constantly attracts the viewer instead of boring him with monotony." [20: p.7] The principle of unfolding spaces builds on its successive change, acquiring a specia structural significance and developed semantics in the form of cinematic demonstration of choreographic numbers.

Noteworthy, the principle of combining different visual positions in the image was discovered long before the advent of cinematography. The American architect Philip Johnson proposed the concept of 'professional' architecture, arguing that the design of space and molding of volumes only supplement the main thing: the organization of processes. According to him, beauty lies in the way we move through space.

Architectural theorist Andrey Ikonnikov wrote in response: "This point of view may seem paradoxical but it emphasizes one of the Greek specificities of architecture very convincingly." [21: p.8] In this example, one can feel and comprehend, with particular fullness, the organicity of artistic thinking and the rare ability of choreographer Leonid Yakobson to harmoniously combine different types of art into a single matter of a coherent ensemble.

"In the second non-traditional theatrical system of open space, not only choreography masters architecture in coexistence, it builds architecture itsel as we have stated, helping the audience to feel as if inside its own spatial structure Maurice Béjart who worked with the French and Russian troupes in Saint Petersburg, made such an attempt of plastic and architectural conceptualizing. Against the background of the Neva embankments, Mikhailovsky Castle, Peter and Paul Fortress, Kazan Cathedral, and Nevsky bridges, unforgettable choreographic images were born, as if filled with the atmosphere of a modern city." [22: p.174]. The panoramic background of the northern city, designed for the unrestrained contemplation of nature, seemed to signify the disappearance of the architectural scenery that had existed in theatrical painting before. The water space of the Neva, with its horizontal length and open sky, became the setting for several choreographic compositions by Maurice Béjart: the Greek Suite, the Act

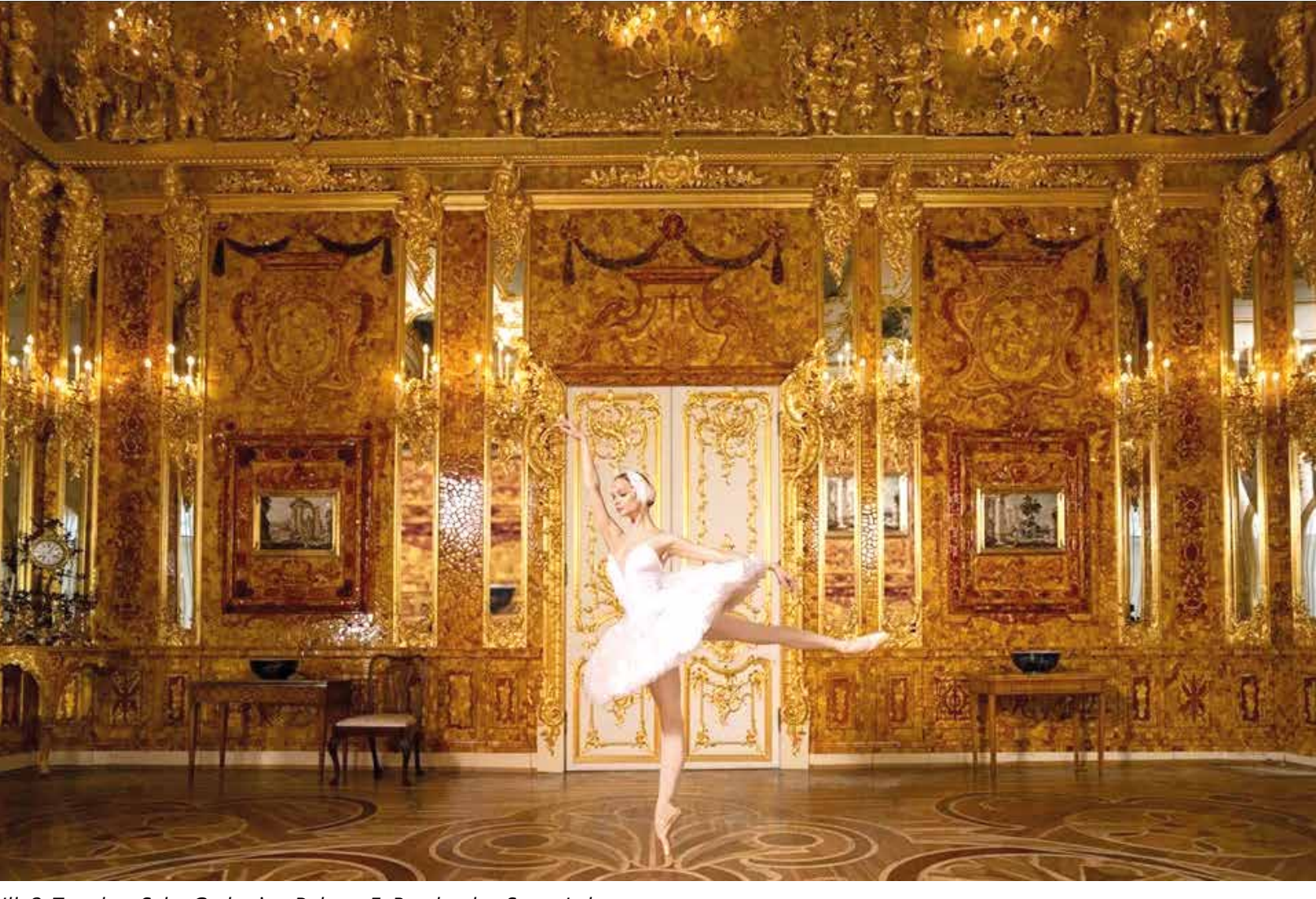

II. 2. Tsarskoe Selo. Catherine Palace. E. Borchenko. Swan Lake

of Shadows from La Bayadère, etc. It was because of its classical exemplarity with the silhouette of the Peter and Paul Fortress in the background that the embankment became a true source of inspiration for Béjart. Here, it is appropriate to address the question of the field and the boundaries of the choreographic image in relation to architecture. After all, in a traditional three-dimensional box dance, action is formed within the given boundaries of the stage portal. In the open air, though, new means for its compositional and narrative deployment methods became available. So, the attraction of architecture to dance was also expressed in the desire of choreographers to experiment with individual structures. The main conceptual direction in the choreographic piece The Knight in the Panther's Skin after the Georgian epic poem by Shota Rustaveli was the tectonic idea: the co-subordination of compositions and dance angles with the aesthetic principles of tectonics and the heroized scale of the architectural forms of the Kazan Cathedral colonnade. The through colonnade allows you to see the entire composition of the semicircular platform and the structure itself, in which the dance is blended with its plastic stereometricity. There is a direct correlation between this greatness and the scale of the changing mass of figure groups of performers, and the stability of the composition in which they realize their being. The synthetic integrity of the monumental style is clearly evident in this piece. The fragments of ballets Vain Precautions and The Creation of the World performed by the French artists of the company Ballet XXV were blended in the light cheerful structure of a landscape park in Saint Petersburg, leaving the stereotypical enclosed space behind and entering the new pictorial and metaphoric structures.

Recently, choreography has tactfully entered the natural space without disturbing the visual connections to the established architecture. Such are the productions of dances and full performances in the open air against the backdrop of architectura structures: Zeus by Andrey Petrov in the ruins of the Temple of Zeus in Olympia (Greece), choreographic numbers shown against the silhouette pattern of the Eiffel Tower in Paris, etc. The need for successful dance obliges the stage director to constantly keep the conditions of the scene in mind. These conditions are not just a formality. They are predetermined by the inner nature of the drama itself The emphasis shifts here due to some deviation from the norm when the viewer's gaze is turned of architectural style comes to the fore. The style primarily to the theatrical action, and the concep 
of architectural environment and the style of choreography are in close relationship with each other. The previously conventional three-dimensional space of the stage box lost some conventionality, though the nature of the choreographic image was not harmed. The uniqueness of the architectural object and the artistry directly related to it influenced the structure of the dance images decisively, so the principle of harmonization became dominant. The requirement for harmonious unity of architecture, space, the artist, and the viewer becomes the principal concept of forming this environment, to influence the feelings. In the uni-

REFERENCES

1. Berezkin, V.I. 2013. The art of scenography of the world theater. Volume 3. Masters of the $16^{\text {th }}$-20 th centuries, Moscow, p. 296

2. Yesaulov, I.G. 2005. Introduction to the aesthetics of classical choreography. Letters to J. G. Noverre, Izhevsk Udmurt University, p. 223

3. Noverre, J.G. 2007. Letters about dance, p. 382

. Vanslov, V.V. 1997. Grigorovich's ballets and matters of choreography, Moscow, p. 302

5. Dubnik, I.O. 1984. The specifics of artistic imagery in choreographic art: an abstract of the dissertation Moscow, p. 22

6. Kondratenko, Yu. 1999. "Synthesis in the choreographic art of the postmodern era / Yu. Kondratenko", The voice of the artist: the problem of synthesis in modern choreography: Materials of the international conference, Volgograd, pp. 16-20.

7. Churko, Yu.M. 1999. The line going to infinity: Subjective notes on modern choreography, Minsk, p. 224

8. Vychuzhanova, L.K. 2009. The language of choreography: philosophical analysis. The abstract of the dissertation for the degree of candidate of philosophical sciences, Ufa, p. 20

9. Gerasimova, I.A. 1998. Philosophical understanding of dance, Questions of philosophy. - 1998, no. 4, p. 50-63. 10. Rappaport A.G. 2012, "Space and substance", ACADEMIA, no. 2,3. pp. 20-23

11. Lebedeva, G.D. 2007. Ballet, semantics and architectonics, St. Petersburg, p. 160

2. Gerdt, O. 1999. Territory of possibilities in motion Netherlands' Institute of Theater, Moscow, p. 28 versality of ancient architecture and dance, their originality blossomed.

Today, the phenomenon of design is perceived not only from the perspective of architectural creativity but also as an integral characteristic of any contemporary creative art form. We have observed this phenomenon in the area of dance practices at various stages of choreographic activity. The very staging work of the choreographer itself, like that of the architect, can be designed in computer programs now, prompting us to talk about the deconstruction of artistic perception and other methods of working with spatial stage composition.
Татьяна Васильевна Портнова доктор искусствоведения, профессор ФГБОУ ВО «Российский государственный университет

им. А. Н. Косыгина» e-mail infotatiana-p@mail.ru Москва, Россия

ORCID ID: 0000-0002-4221-3923
13. Dutsev, M. V. Integration of art into the latest architecture [electronic resource]. URL: https://bibl.nngasu.ru/ electronicresources/uch-metod/architecture/850493. pdf (accessed: 25.07.2021)

14. Gelfond, A.L., Dutsev M.V. 2010. "Architectural and artistic synthesis as a means of dialogue", Privolzhsky Scientific Journal, N. Novgorod: NNGASU, no. 4, pp. 147-152.

15. Hakobyan-Shupp, R. 1999. "Global dance: the creative process, the development of a new sphere of dance", The voice of the artist: the problem of synthesis in modern choreography: Materials of the international conference, Volgograd, pp. 41-51

16. Evin, I. A. 1993. Synergetics of art, Izhevsk, p. 171.

17. Portnova, T.V. 2014. "Architectonic principles in ballet (Dialogue of arts in a spatial environment)" International Journal of Experimental Education, no. $1-2$, p. 170

18. Remez, O. Ya. 1982 Mise en scène and stage action Moscow, GITIS, p. 103

19. Alone with time. (Interview with Maurice Béjart). 1995. Musical life, no. 7-8. p. 7-8

20. Portnova, T.V. "The category of space and the principles of architectonics in the structure of a ballet performance", space and time: theories, concepts, paradigms, vol. 3, no. 2, p. 7

21. Ikonnikov, V.A. 1983. The artistic language of architecture. Problems of space and architecture Moscow, p. 8

22. Portnova, T.V. 2014. "Architectonic principles in ballet (Dialogue of arts in a spatial environment)" International Journal of Experimental Education, no. $1-2$, p. 174

DOI: 10.36340/2071-6818-2021-17-4-79-90

\section{АРХИТЕКТУРНОЕ ПРОСТРАНСТВО В ТАНЦЕ КАК ХУДОЖЕСТВЕННО-ОБРАЗНАЯ СИСТЕМА}

Аннотация: В ходе исследования рассматриваются выразительные средства танца и архитектуры устанавливаются общее и специфическое в природе их художественного языка, выявляются степень взаимодействия архитектурных принципов с танцевальной драматургией и хореографической композицией, анализируются примеры интерпретации танцевальных постановочных решений в архитектурном пространстве. Анализируются вудожегектурном пространсте. Анализируются художебалетмейстерских решений, происходящие в разбалетмейстерских решений, происходящие в разс перспективизма декораций на сценической плос парспективизма декораций на сценической плоцадке и световой архитекуры XVII в. автор переобстановочного спектакл XIX в. ихореографическим экспериментам начала XX в. B стате ор стся, что наиболее интереснве проектн отн, что а с мел сорег, ориги иальных приемов взаиморействия хореогр ории и архитектры постановки танцев

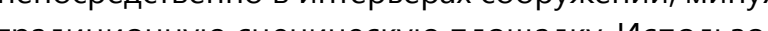
традиц ион не сценическуо площа иу. Истользоохная идея движения человека в пространстве, охват идещ ая зритела, появляется здесь в резульТа

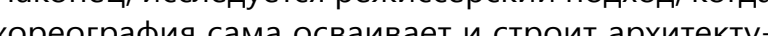

Танец в архитектурном пространстве - сложная, многоаспектная проблема, находящаяся на пересечении искусства, философии и инженерных технологий. Настоящее исследование рассматри вает данную тему как художественно-эстетическую категорию в контексте выразительных средств хореографического искусства, находит своё творческое осмысление и многообразие форм художественного отображения пространства посредством танца. ру, помогая зрителю ощутить себя словно внутри собственной пространственной структуры. Этот своеобразный художественно-визуальный синтез предстаёт в динамике жанрового и стилевоо авторского сценического контекста. Изучение специфики балета как зрелищного явления представляется насущной исследовательской задачей, тосколу именно балет, как никакой другой жанр и рального искусства, оставил в наследии XX нотан, вероятно, XXI веку чрезвычайно разцы пространственно-сценического творчества Проблема интерпретаци танца творчества. ном пространстве как самостоятельний предмет исследования имеет важное значение в связи со структурой и эволюиией художественного обра за в современном хореогра иическом искусте а ва фоне постмо хорностких совком искусстве лев

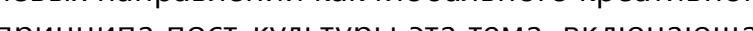
стано шир одной из клочические ассоциации, художественного пр

архитектурное пространство К совенно-образная система, синтез архитектуры и танца.

Если проблемы морфологии танца, его языковой природы достаточно освещены в современной научной литературе, то вопрось архитектурного пространства как необходимой субстанции, существующей в хореографическо искусстве, становятся редким объектом внимания исследователей. Сценическое пространство, от его истоков до нового времени, формируе мое методами сценографии, являлось предме том анализа В. Березкина [1]. Пространство как 
выразительное средство в композиции танца изучается будущими балетмейстерами в учебных курсах, что позволяет сформировать осознанное отношение и мотивацию в работе со сценографическим целым. Ж. Новерр рассматривал сценическую площадку как геометрическую систему в контексте понимания композиционной деятельности танцмейстера и организации элементов танца с целью создания стройной гармонии хореографического сочинения [2; 3$]$.

Поставленная в настоящей статье проблема второстепенным образом затрагивается в балетоведческой литературе в связи с размышлениями теоретиков танца, а также в контексте творчества ряда хореографов: М. Петипа, М. Фокина, К. Голейзовского, Л. Якобсона, Ю. Григоровича, Б. Эйфмана, М. Грэхем, М. Р. Фон Лабана, М. Каннигрехэм, М. Бежара, Е. Панфилова,-отразивших в своём творчестве концептуальное, художественно-пространственное видение природы танца $[4 ; 5 ; 6]$. Их мнения сходятся в том, что пространство является своеобразным объектом хореографического содержания, которое приходится каждый раз заново интерпретировать. Описанные Е. Чурко приёмы современной хореографии функционируют в контексте эстетики перформативности как пути образования новых связей между элементами художественно-пространственной композиции, а также в отношении зрительского восприятия [7].

Значительная группа исследований рассматривает театральное пространство как философскую категорию $[8 ; 9 ; 10]$. Так, Г. Лебедева, оперируя понятиями балет, семантика, архитектоника с позиций системного подхода и синергетической парадигмы, анализирует пространственно-временные параметры балетного спектакля и специфику взаимодействия составляющих его компонентов [11]. О. Гердт в исследовании «Территория возможностей. В движении» предлагает рассмотреть изменчивую природу актёрской пластики, которая позволяет проявляться различным простра ная в пространственную среду, может раскрывать множественность путей понимания театрального образа, а также даёт потенциал для возникновения новых отношений к его содержанию [12]

Сейчас можно встретить размышления об интегративном принципе современной архитектуры: «Многоэлементные формы творчества прежде всего, театр, кино, телевидение, современная хореография, соотносятся с актуальны- ми архитектурными тенденциями «режиссуры» и «зрелищности». Несмотря на условность такого родства, ряд явлений и подходов сферы зрелищных искусств можно охарактеризовать как актуальные принципы архитектуры: сценарность подчеркнутая визуальная выразительность, выстраивание объёмов и пространств как «мизансцен» спектакля, архитектурность «декорации», смена «кадров» пространственных впечатлений в движении» [13]. Действительно, искусство архитектуры, так же, как и искусство танца, издав на следует закону художественной интеграции а архитектор и хореограф применяют художе ственный синтез как разновидность комплексного интеграционного метода профессиональной деятельности $[14 ; 15 ; 16]$

Вместе с тем, несмотря на приведённые источники, полноценный аналитический подход с позиций архитектурной составляющей балетного произведения в искусствоведении остаётся несформированным.

Методологическая концепция исследова ния основана на принципах целостного изучения функционирования танца в архитектурном пространстве: от философско-эстетических, художественно-образных до языково-стилистических вопросов его рассмотрения. Исследуя некоторые исторические аспекты синтеза танца и архитектуры, мы оцениваем события и явления театральной жизни с современных позиций, учитывая, что избранная тема - содружество драматурга, режиссёра и архитектора - имеет непосредственно значение для творческой практики наших дней и актуальна не только для российского, но и для мирового многонационального театра.

В основе любого хореографического спектакля должна лежать прочная архитектоническая конструкция. Ещё К. Станиславский высоко ставил искусство мизансцены, требовал точной схемь перемещений актёра в пространстве. Он называл актёра инженером, архитектором роли. «Хореографический образ не может существовать без пространственной структуры, без найденного продуманного конструктивного принципа, определяющего пульс всей постановки. Корде балетные массы, разнообразно формирующиес в ходе спектакля, также образуют пространственную среду и обладают своего рода тектоникой. Архитектоника балетного спектакля состоит и двух вербальных компонентов. Один уходи в изображение, художественное оформление, организацию пространства, а другой сохраняется в танце» [17: с. 170]. С. Я. Ремез отметил: «Режиссура - искусство строительное» [18: с. 103] спектакля - увлекательная, но не простая задача для хореографа.

Возникшая в Италии в XVI в. сцена - коробк в обстановке придворных архитектурных представлений и примитивные ярмарочные подмостки, на которых бродячие актёры увеселяли народную толпу, собравшуюся на площади, создали две системы театральных пространств, которые можно обозначить как замкнутое и открытое Замкнутое, существующее на сцене, внутри интерьера театрального здания, и открытое, распространившееся на природно-архитектурную среду. Французский хореограф М. Бежар характеризовал архитектуру как искусство, серьёзно влияющее на балет: «Я много работал с архитекторами, может быть, не с очень знаменитыми. Они мне создали новое сценическое пространство, составляющее важный элемент спектакля. Mои самые лучшие спектакли идут на итальянской сцене с поднимающимся в глубине полотном. У меня сцены каждый раз оборудованы по-разному» [19: с. 7-8].

Начиная С XVI в. на сцене развиваются приёмы перспективизма, способные зрительно углубить архитектонику сценического действия. Даже ус ловно-абстрактные декорации с изображением архитектурных строений могут подчеркнуть и усилить пространственно-зрительную разработку спектакля, взаимную обусловленность танцовщи ков и среды. Сопоставление линейной перспективы в двухмерной декорации эпохи Ренессанс с пространством реальной архитектуры невольно приводит к иллюзорному сближению онтологических систем этих видов творчества.

Можно наблюдать иную концепцию пространства, основанную на взаимоотношении световой архитектуры и танца,- это вовсе не изобретение современной эпохи. Она уже была заложена в скрытом виде в образной структуре усадебной архитектуры царских увеселительных резиденций XVIII в. Москвы и Санкт-Петербурга: Царицыно, Архангельского, Кусково, Останкино, Петергофа, где момент театрализации был особо значим. Сама архитектура этих ансамблей с их регулярными планировочными принципами была рас считана на театрализованную пространственную игру, смену процессий и также приобретала теа- тральный характер. Садово-парковая архитектура того времени считалась равноценным искусством, наряду с другими. Феерия, создаваемая декоративным характером цветных фонарей, рождала образ иллюзорной световой архитектуры, стала генератором развёрнутого пространства, хотя ещё и не достигла в плане его организации геометризированной логики световых лучей, подобной современной сценической аппаратуре. При этом здесь же следует учитывать условность стилевых характеристик самих архитектурных ансамблей и отсутствие чётких границ между ними. Иногда архитекторы, садовники и организаторы театрализованных мероприятий сочетали черты разных стилевых направлений, работали на их стыке, исходя из декоративно-эмоциональных принципов, а не из функционально-технических дополняя таким образом структурную пластику орнаментальной.

Монументальное построение большого обстановочного спектакля М. Петипа и Л. Иванова конструктивистские эксперименты К. Голейзовского, движение танцевальных форм, их трансформация и сопоставление у Дж. Баланчина - все это примеры использования различных пространственных систем. Фигуры артистов сами создают архитектуру, ориентируют зрителя на собственную пространственную структуру. Танцу ющие у М. Петипа и Л. Иванова тяготеют к сим метрии форм, синхронной ансамблевости, при этом сохраняя живую непосредственность каждого образа. Кордебалетные группы «Лебедей», «Виллис», «Теней» в «Лебедином озере», «Жизе ли», «Баядерке», выстраиваясь параллельными диагональными и иными рядами на планшете сцены, словно генетически создавали ту удиви тельную геометрию танца, без которой хореографию этих балетов представить невозможно. Хореограф-экспериментатор начала XX в. К. Го лейзовский часто приводил актёрские группы к элементарной схематической простоте. Вер тикальное, а не горизонтальное, как у Л. Иванова и М. Петипа, направление, приобретаемое з счёт сверхусложнённости, развивалось ввысь. В оформлении он использовал лестницы, мость и другие архитектурные элементы (здесь происходило взаимодействие архитектонической структуры оформления с тектоникой фигур ар тистов в пространстве). Это было самое крайнее проявление хореографического тектонического рационализма (1920г.), обнаженная конструк- 
тивность которого была так созвучна архитектурным поискам того времени. В этом своём виде абстрактные бутафорские строения находят себе место как предметное наполнение сценической среды и воздействуют в унисон с рационалистской архитектурой как связанные с ней элементы, привносящие в хореографию свой конструктивно-объёмный акцент.

«Примером смелого и оригинального приёма взаимодействия хореографии и архитектуры может служить постановка танцев непосредственно в интерьерах сооружений, минуя традиционную сценическую площадку. Идея движения челове ка в пространстве по направлению из зала в зал, волнение, охватывающее зрителя в результате смены конкретных, последовательно меняющихся впечатлений, наглядно были раскрыты в постановке хореографических миниатюр Л. Якобсона в залах музея керамики усадьбы «Кусково». Основой композиции стало открытое пространство, анфилада залов, не имеющих чётко очерченных границ и симметричных осей, но в то же время подчинённых определённой ритмической закономерности. Это пространство не топографическое и не математическое, а живое и действующее. Движение танца переходит из одного зала в другой. Здесь присутствует энергичное развертывание действия, резкое чередование сцен, быстрая смена фонов, обыгрывание деталей, ракурсный взгляд. При движении взгляда в поле зрения попадают многочисленные архитектурные элементы и детали (двери, проёмы, окна, колонны, люстры, декорации и т.п.), участвующие в создании внутреннего эмоционального настроя. Контрасты пространств, форм, фактур, направлений рождают ту множественность впечатлений, которая постоянно притягивает зрителя, не утомляя его однообразием» [20: с. 7]. Принцип развёртывания пространств, построенный на их последовательной смене, приобретает особую структурную значимость и развитую семантику в формате кинематографической демонстрации хореографических номеров.

Следует заметить, что принцип совмещения в изображении различных зрительных позиций был открыт задолго до появления кинематографа. Американский архитектор Ф. Джонсон предложил концепцию «профессиональной» архитектуры утверждая, что проектирование пространства и лепка объёмов лишь дополнительны к главному - организации процессов. По его мнению, красота заключается в том, как мы движемся в пространстве.

Теоретик архитектуры А. Иконников в отве на это пишет: «Такая точка зрения может показаться парадоксальной, но одну из граней специфики архитектуры она подчёркивает весьма убедительно» [21: с. 8]. На этом примере можно с особой полнотой почувствовать и постичь ту органичность художественного мышления, редкое умение хореографа Л. Якобсона гармонично соединять различные виды искусства в единую материю согласованного ансамбля.

«Во второй нетрадиционной театральной системе открытого пространства хореография осваивает архитектуру не только в сосуществовании она сама, как мы констатировали, строит архитектуру, помогая зрителю ощутить себя словно внутри собственной пространственной структуры. Такую попытку пластически-архитектурного осмысления осуществил М. Бежар, работавший с французской и русской труппой в Санкт-Петербурге. На фоне набережных Невы, Михайловско го замка, Петропавловской крепости, Казанского собора, Невских мостов рождались незабываемые хореографические образы, словно наполненные атмосферой современного города» [22: c. 174]. Панорамный фон северного города, рассчитанный на естественное созерцание природь словно означал исчезновение архитектурной де корации, существовавшей ранее в театральной живописи. Водное пространство Невы с её гори зонтальной протяжённостью и открытым небом стало местом для демонстрации ряда хореографических композиций М. Бежара - «Греческой сюиты», акта Теней из «Баядерки» и др. Именно в силу своей классической идеальности с силуэтом Петропавловской крепости на заднем плане набережная стала для М. Бежара истинным источником вдохновения. Здесь по отношению к архитектуре уместно затронуть вопрос о поле и границах хореографического изображения. Вед в условиях традиционной трёхмерной коробки танцевальное действо формируется в заданных границах портала сцены, на открытом воздухе оно получило возможность найти средства для сво их приёмов композиционного и сюжетного развертывания. Так, тяготение архитектуры к танцу выражалось и в стремлении балетмейстеров экспериментировать с отдельными сооружениями Основной концептуальной установкой в хореографическом номере «Витязь в тигровой шкуре на тему грузинской легенды Ш. Руставели являлась художественно-тектоническая идея, соподчине ние композиций и ракурсов танца с эстетическими принципами тектоники героизированным масштабам архитектурных форм колоннады Казанского собора. Сквозная колоннада позволяе видеть всю композицию полукруглой площадки и само сооружение, в которые вписан танец с его пластической стереометричностью. Между этим величием и масштабом меняющейся массы фигурных групп исполнителей, устойчивостью композиции, в которой они реализуют своё бытие, оказывается прямая зависимость. В этом номере ярко проявилась синтетическая целостность монументального стиля. Фрагменть балетов «Тщетная предосторожность» и «Сотворение мира» в исполнении французских артистов труппы «Балет XX века» были словно вписань в светлый жизнерадостный строй пейзажного парка Санкт-Петербурга, отошли от стереотипного замкнутого пространства и вышли в новые живописно-образные структуры.

В последнее время хореография тактично входит в естественное пространство, не нарушая визуальных связей со сложившейся архитектурой. Таковы постановки танцев и целых спектаклей на открытом воздухе на фоне архитектурных сооружений: «Зевс» А. Петрова в руинах храма Зевса в Олимпии (Греция), хореографические номера, показанные на фоне силуэтного рисунка Эйрелевой башни в Париже и др. Необходимость действенного танца обязывает режиссёра-постановщика постоянно помнить об условиях сцены.
Эти условия имеют не формальное значение. Они предопределены внутренней природой самой драматургии. Некоторое отклонение от нормы когда взгля зрителя обращён, прежде всего, на театральное действо, здесь акценты смещаются, понятие архитектурного стиля выходит на пер вый план. Стиль архитектурной среды и стиль хореографии находятся в тесных отношениях друг с другом. Условное трёхмерное пространство сценической коробки сделалось менее условным это не разрушило природу хореографического изображения. Уникальность архитектурного объекта и непосредственно связанная с ним художественность решительным образом повлияли на структуру образов танца, доминирующим стал принцип гармонизации. Требование гармонического единства архитектуры, пространства, арти ста и зрителя, с целью воздействия на его чувства становится основной концепцией формирования этой среды. В универсуме старинной архитектуры и танца стала ощущаться их оригинальность. На сегодняшний день феномен проектирования воспринимается не только с позиций архитектурного творчества, но и как неотъемлема характеристика всего современного креативного искусства. Это явление мы наблюдали в сфере танцевальных практик на различных этапах хореографической деятельности. Сама постановочная работа хореографа, как и архитектора, начинает моделироваться в компьютерных программах когда можно говорить о деконструкции художественного восприятия и других методах работ с пространственной сценической композицией. 


\section{БИБЛИОГРАФИЯ:}

1. Березкин В. И. Искусство сценографии мирового театра. - Том 3. Мастера XVI-XX вв. / В. И. Березкин.-М.: Едиториал УРСС, 2013.- 296 с.

2. Есаулов И. Г. Введение в эстетику классической хореографии. «Письма к Ж. Ж. Новерру» / И. Г. Есаулов.-Ижевск: Удмуртский университет, 2005.$223 \mathrm{c}$.

3. Новерр Ж. Ж. Письма о танце / Пер. с фр. под ред. А. А. Гвоздева. -2-е изд., испр.-СПб.: Лань, 2007.382 с.

4. Ванслов В. В. Балеты Григоровича и проблемы хореографии / В. В. Ванслов.- М.: Искусство, 1997.302 c.

5. Дубник И. О. Специфика художественной образности в хореографическом искусстве: автореферат дис. / И. О. Дубник.-М., 1984. - 22 с.

6. Кондратенко Ю. Синтез в хореографическом искусстве эпохи постмодерна / Ю. Кондратенко // Голос художника: проблема синтеза в современной хореографии: Материалы международной конференции.-Волгоград, 1999.-С. 16-20.

7. Чурко Ю. М. Линия, уходящая в бесконечность: Субъективные заметки о современной хореографии.-Минск: Полымя, 1999.-224 с.

8. Вычужанова Л. К. Язык хореографии: философский анализ: автореферат диссертации на соискание ученой степени кандидата философских наук / Л. К. Вычужанова.-Уфа, 2009. - 20 с.

9. Герасимова И. А. Философское понимание танца / И. А. Герасимова // Вопросы философии.-1998. № 4.- C. 50-63.

10. 10. Раппапорт А. Г. Пространство и субстанция / А. Г. Раппапорт // ACADEMIA. - 2012. - № 2, 3.С. 20-23.

11. Лебедева Г. Д. Балет, семантика и архитектоника / Г. Д. Лебедева.-СПб.: Лань, 2007.- 160 с.

12. Гердт О. Территория возможностей. В движении. Институт театра Нидерландов / О. Гердт.-М., 1999.C. 28 .
13. Дуцев М. В. Интеграция искусства в новейшую архитектуру. [Электронный ресурс].- URL: https://bibl.nngasu.ru/electronicresources/uch-metod/ architecture/850493.pdf (дата обращения: 25.07.2021).

14. Гельфонд А.Л., Дуцев М.В. Архитектурно-художественный синтез как средство диалога / А. Л. Гельфонд, М.В. Дуцев // Приволжский научный журнал. - Н. Новгород: ННГАСУ, 2010.— № 4.—С. 147152.

15. Акопян-Шупп Р. Глобальный танец: творческий процесс, развитие новой сферы танца / Р. Акопян-Шупп // Голос художника: проблема синтеза в современной хореографии: Материалы международной конференции.-Волгоград, 1999.-С. 41-51.

16. Евин И. А. Синергетика искусства / И. А. Евин.-М.; Ижевск: РХД, 1993.-С. 171.

17. Портнова Т.В. Архитектонические принципы в балете (диалог искусств в пространственной среде) / Т. В. Портнова // Международный журнал экспериментального образования. - 2014. — № 1-2.— C. 170.

18. Ремез С. Я. Мизансцена и сценическое действие / С. Я. Ремез.- М.: ГИТИС, 1982.-С. 103.

19. Наедине со временем (Интервью с М. Бежаром) // Музыкальная жизнь. - 1995. - № 7-8.- С. 7-8.

20. Портнова Т. В. Категория пространства и принципы архитектоники в структуре балетного спектакля // Пространство и время: теории, концепции, парадигмы.-Т. 3.- Вып. 2.-С. 7.

21. Иконников В. А. Художественный язык архитектуры. Проблемы пространства и архитектуры / В. А. Иконников.-М.: Искусство, 1983.-С. 8.

22. Портнова Т.В. Архитектонические принципы в балете (диалог искусств в пространственной среде) / Т. В. Портнова // Международный журнал экспериментального образования. - 2014. — № 1-2.— С. 174. 